\title{
THE SIGNIFICANCE OF PLASMA PHOSPHATASE IN THE DIAGNOSIS AND PROGNOSIS OF RICKETS
}

\author{
BY
}

\section{NOAH MORRIS, MARY M. STEVENSON, OLIVE D. PEDEN AND} JEAN M. D. SMALL.

(From the Department of Paediatrics, Glasgow University, and the Biochemical Laboratory, Royal Hospital for Sick Children, Glasgow, and Public Health Department, Stobhill Hospital, Glasgow.)

Although it is true that ordinary clinical examination suffices for the diagnosis of moderate degrees of rickets, most workers would agree that something more is necessary for the detection of milder forms of the disease, when the metabolic disturbances are not sufficiently great or have not continued long enough to produce clinical manifestations. For this purpose skiagrams have been used to great advantage both in practice and as an instrument of research. There are, however, several drawbacks associated with their employment. In the mildest forms of the disease the interpretation of the skiagrams is a matter of considerable difficulty; indeed, it may be classified as a subjective test. In the second place it is not possible in many cases to determine whether any healing is taking place until a series of at least three skiagrams taken at weekly intervals is available. For this reason it is difficult to estimate by x-rays alone, the initial stages of healing. Undoubtedly the most accurate method of determining the presence or absence of the rachitic process and its severity is by estimating the actual retention of minerals. Unfortunately this is laborious, timeconsuming and quite unsuited for general use in making prolonged studies on a series of patients. Resort has therefore been made to chemical examination of the blood. The serum calcium does not alter markedly in uncomplicated rickets but a reduction of the inorganic phosphorus has long been used as a valuable indication of the presence of rickets. This latter test suffers from some of the defects associated with x-ray examination, in that there is usually little change in the level of serum phosphorus for two to three weeks after the start of antirachitic therapy, whereas metabolic studies have shown that within one week, administration of ritamin D leads to a marked increase in mineral retention.

Freudenberg $^{1}$ points out that a low serum phosphorus is not pathogromonic of rickets since it may occur in pneumonia and other acute infections, muscular dystrophies, myxoedema and coeliac disease. Furthermore, Hess $^{2}$ and others ${ }^{3}{ }^{4}$ have shown that sometimes the phosphorus content of the serum may be normal even when there are definite clinical 
manifestations of active rickets. Marfan ${ }^{5}$ also states that the decrease in serum phosphorus cannot be regarded as a regular feature of rickets. It certainly is within the experience of most workers that occasionally the serum phosphorus is within normal limits although the clinical and $\mathrm{x}$-ray findings indicate an active stage of the disease. Bodansky and $\mathrm{Jaffe}^{6}$ found that while serum phosphorus is generally low in untreated rickets, it rapidly responds to treatment, so that when small amounts of a vitamin $D$ preparation have been given for a short time a relatively high value for serum phosphorus does not give a reliable indication of the stage or extent of healing. This has also been observed by the present writers on several occasions. Conversely it has been shown that serum phosphorus may remain low although signs of healing are present both on clinical and $\mathrm{x}$-ray examinations.

The product of the calcium and phosphorus values of the serum has for some time been accepted by many as a valuable index of the rachitic process. A product above forty indicates healing and one below thirty an active stage. But its significance has been disputed by $\mathrm{Hess}^{2}$ who obtained products above forty without signs of healing: on several occasions we have had the same experience.

Since Robison's work was first applied to clinical conditions, variations of the plasma phosphatase in rickets have been studied with a view to utilizing its estimation as a means of determining the presence and stage of the rachitic process.

Kay' found that in various types of human rickets the plasma phosphatase was increased. Smith and Maizels' stated that in rachitic infants the plasma phosphatase which prior to treatment was about two-and-a-half times the normal average, decreased gradually after the commencement of antirachitic therapy, arriving within normal limits only when healing was complete. Stearns and Warweg', however, found that the plasma phosphatase was still above normal limits even when complete healing was shown in the skiagrams. Bodansky and $\mathrm{Jaffe}^{6}$ obtained in rickets much higher values for plasma phosphatase than did Smith and Maizels ${ }^{8}$ : this they attributed to the fact that their patients were negro infants on whom sunlight would have less prophylactic effect than on white children. Smith ${ }^{10}$ has stated that the plasma phesphatase is probably a much more sensitive and accurate index of abnormal bone metabolism than is either serum calcium or phosphorus.

The purpose of this communication is an attempt to assess the value of plasma phosphatase as a diagnostic test for rickets and also as a means of determining the presence and rate of healing. The results are based on the examination of 506 infants and children in the first two years of life who either had manifest rickets or might possibly have been suffering from the effects of vitamin $D$ insufficiency. They were all in-patients in the medical wards of the Royal Hospital for Sick Children, Glasgow, or the children's wards of Stobhill Hospital. The method employed for estimating phosphatase was that devised by Jenner and Kay ${ }^{11}$. Using this method we have found in a series of healthy infants of the first two rears of life that the limits for plasma phosphatase fell between 3.4 and 10.5 units with an average of 6.92 and any value above 11.0 has been considered to be higher than normal. 


\section{PLASMA PHOSPHATASE IN THE DIAGNOSIS OF RICKETS}

\section{Plasma phosphatase in the presence of clinical evidence of rickets}

The first question to be answered is whether clinical and $\mathrm{x}$-ray signs cf rickets are always accompanied by an increased value for plasma phosphatase or not. Of $2 \pi 0$ cases with positive clinical or x-ray findings, 22. (84.1 per cent.) showed an increased value for phosphatase, while in $\mathbf{4 3}$ (159 per cent.) the figures were within normal limits (table 1). In only

TABLE 1.

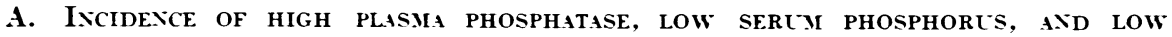
CALCICM-PHOSPHORL'S PRODLCT IN CASES WITH CLINICAL OR RADIOGRAPHIC SIGNS OF RICKETS.

\begin{tabular}{|c|c|c|c|c|c|c|}
\hline & \multicolumn{2}{|c|}{ Plasma phosphatase } & \multicolumn{2}{|c|}{ SERCM PHOSPHORLS } & \multicolumn{2}{|c|}{$\begin{array}{c}\text { C.ALCILM-PHOSPHORL'S } \\
\text { PRODLCTS }\end{array}$} \\
\hline & High & NorMal & Low & Normal & Low & Noryal \\
\hline $\begin{array}{l}\text { No. of cases } \\
\text { Percentage }\end{array}$ & $\begin{array}{l}227 \\
84 \cdot 1\end{array}$ & $\begin{array}{c}43 \\
15 \cdot 9\end{array}$ & $\begin{array}{r}174 \\
68 \cdot 0\end{array}$ & $\begin{array}{c}82 \\
32 \cdot 0\end{array}$ & $\begin{array}{l}175 \\
81 \cdot \%\end{array}$ & $\begin{array}{c}39 \\
18 \cdot 3\end{array}$ \\
\hline
\end{tabular}

B. INCIDENCE OF CLINICAL OR RADIOGRAPHIC SIGNS OF RICKETS IN CASES WITH HIGH PLASMA PHOSPHATASE, LOW SERLM PHOSPHORLS AND LOW CALCICM-PHOSPHORLS PRODLCT.

\begin{tabular}{|c|c|c|c|c|c|c|c|}
\hline & \multicolumn{2}{|c|}{$\begin{array}{l}\text { HIGH PLASMA } \\
\text { PHOSPHATASE }\end{array}$} & \multicolumn{2}{|c|}{$\begin{array}{l}\text { LOW SERTM } \\
\text { PHOSPHORTS }\end{array}$} & \multicolumn{3}{|c|}{$\begin{array}{c}\text { LOW CALCILYI- } \\
\text { PHOSPHORLS PRODCT }\end{array}$} \\
\hline & SIGNs & No sigxs & Sigxs & No sigxs & SIGNS & No & SIGNS \\
\hline $\begin{array}{l}\text { No. of cases } \\
\text { Percentage }\end{array}$ & $\begin{array}{l}227 \\
69 \cdot 9 \\
\end{array}$ & $\begin{array}{c}101 \\
30 \cdot 1\end{array}$ & $\begin{array}{l}174 \\
57 \cdot 8\end{array}$ & $\begin{array}{l}12 \% \\
42 \cdot 2\end{array}$ & $\begin{array}{l}175 \\
57 \cdot 7\end{array}$ & & $\begin{array}{l}128 \\
12 \cdot 3\end{array}$ \\
\hline
\end{tabular}

five of the latter group of $\mathbf{4 3}$ was the rickets at all marked: in one of these the estimation of the phosphatase was repeated three times within ten days with practically icientical results. It would appear, therefore, that while in the majority of cases of rickets there is an increase of plasma phosphatase there is a small grcup in which such an increase does not occur.

In 101 cases an increased value for phosphatase was obtained without either clinical or $x$-ray signs of rickets. Of these, 59 had low values for the serum phosphorus or the calcium phosphorus prcduct, suggesting that a rachitic process might have been present. Opportunity was afforded of reexamining five of the 42 patients with normal values for serum phosphorus some months later after the infants had been sent home but had not been receiving regular antirachitic therapy owing to the negligence of the parents. In all, definite signs of rickets were present (table 2). This tempts the

TABLE 2.

\begin{tabular}{|c|c|c|c|c|c|c|c|}
\hline Naye & Date & Clais. & X-RAY & $\begin{array}{l}\text { Phospha- } \\
\text { TASE, CNITS }\end{array}$ & $\begin{array}{l}\text { Ca IG I. } \\
\text { PER CENT. }\end{array}$ & $\begin{array}{l}\text { P. MGII. } \\
\text { PER CENT. }\end{array}$ & $\mathrm{Ca} \times \mathrm{P}$. \\
\hline \multirow[t]{2}{*}{ W. P. } & 2. 5.35 & - & - & $18 \cdot 6$ & $9 \cdot 4$ & $4 \cdot 8$ & $45 \cdot 1$ \\
\hline & 26. 2.36 & - & $T$ & $15 \cdot 0$ & $9 \cdot 6$ & $3 \cdot 1$ & $29 \cdot 8$ \\
\hline \multirow[t]{2}{*}{ J. MeD. } & 25. 4.35 & - & - & 13.5 & $9 \cdot 0$ & $4 \cdot 5$ & $40 \cdot 5$ \\
\hline & 20.10 .35 & - & $T$ & $9 \cdot 5$ & $9 \cdot 4$ & $4 \cdot 2$ & $39 \cdot 5$ \\
\hline \multirow[t]{2}{*}{ R. G. } & 28.10 .35 & - & - & $18 \cdot 8$ & $9 \cdot 8$ & - & - \\
\hline & 7. 7.36 & - & - & $14 \cdot 5$ & $9 \cdot 4$ & $5 \cdot 6$ & $52 \cdot 6$ \\
\hline \multirow[t]{2}{*}{ J. MeG. } & 31.10 .35 & - & - & $15 \cdot 0$ & $9 \cdot 8$ & $4 \cdot 1$ & $40 \cdot 2$ \\
\hline & 8. 7.36 & $T$ & $\div$ & $10 \cdot 8$ & $9 \cdot \overline{\mathbf{5}}$ & $4 \cdot \pi$ & $44 \cdot \pi$ \\
\hline \multirow[t]{2}{*}{ W. R. } & 28.10 .35 & - & - & $16 \cdot 0$ & $9 \cdot 3$ & $4 \cdot 6$ & $42 \cdot 8$ \\
\hline & 24. 7.36 & + & - & $15 \cdot 4$ & $9 \cdot 6$ & 35 & $33 \cdot 6$ \\
\hline
\end{tabular}


suggestion that a high plasma phosphatase in a child of an age prone to rickets and without other bone disease may be an earlier manifestation of a rachitic state than that provided br ordinary clinical or x-ray examination.

It is also evident from the data in table 1 that a high plasma phosphatase is more frequently associated with clinical evidence of rickets than is a reduced serum phosphorus. Of 256 cases with rickets, only 68 per cent. (17.) had a low serum phosphorus, while $84 \cdot 1$ per cent. had an increased value for plasma phosphatase. The relationship between a reduced value for the calcium-phosphorus prodnct and clinical evidence of rickets resembles that found with phosphatase: $81 \cdot \tau$ per cent. of 175 patients had a low product. It would appear also that in the first two years of life the chances of a high plasma phosphatase being associated with rickets are greater than those of a low serum phosphorus or low product. Of 328 cases with high phosphatase $69 \cdot 9$ per cent. (22\%) had rickets, while of 301 with low phosphorus only 5\%.8 per cent. (174) and

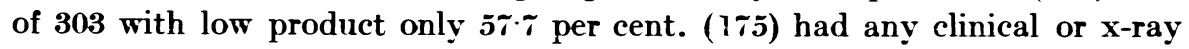
evidence of rickets.

From these figures the conclusion is justified that as far as blood examination is concerned plasma phosphatase is probably the most delicate test of rickets. Nevertheless although the correlation is close it would be unwise to use the phosphatase value alone as conclusive evidence of the presence or absence of rickets.

Height of phosphatase and intensity of the rachitic process

The highest value obtained in the series was $3 \% \cdot 2$ units, about five times the normal average. This is relatively not as high a figure as many of those reported by Bodansky and $\mathrm{Jaffe}^{6}$ but none of the present series of patients could be classed as a very severe case of rickets. Table 3 shows the distribution of phosphatase values. Owing to the practical impossibilitr of devising an accurate test for estimating moderate differences in the degree of rachitic involvement in the human subject it is difficult to compare one patient with another unless there are marked differences in the clinical and $x$-ray findings. A general survey of the series indicates that in a general way the height

TABLE 3.

Distribltion of phosphatase valtes.

\begin{tabular}{|c|c|c|c|c|c|c|c|}
\hline $\begin{array}{l}\text { Phospha- } \\
\text { tase, units }\end{array}$ & $2 \cdot 6-6 \cdot 0$ & $6 \cdot 1-11 \cdot 0$ & $11 \cdot 1-15 \cdot 0$ & $15 \cdot 1-20 \cdot 0$ & $20 \cdot 1-25 \cdot 0$ & $25 \cdot 1-30 \cdot 0$ & Above $30 \cdot 1$ \\
\hline $\begin{array}{l}\text { No. of cases } \\
\text { with no clin. } \\
\text { or X-ray } \\
\text { evidence of } \\
\text { rickets. }\end{array}$ & $\begin{array}{l}\%(11 \cdot 4 \\
\text { per cent.) }\end{array}$ & $\begin{array}{l}108(45 \cdot 8 \\
\text { per cenl.) }\end{array}$ & $\begin{array}{l}64(2 \tau \cdot 1 \\
\text { per cent.) }\end{array}$ & $\begin{array}{l}37(15 \cdot 7 \\
\text { per cent.) }\end{array}$ & $\mathbf{0}$ & $\mathbf{0}$ & $\mathbf{0}$ \\
\hline $\begin{array}{l}\text { No. of cases } \\
\text { with clin. } \\
\text { or X-ray } \\
\text { evidence of } \\
\text { rickets. }\end{array}$ & $\begin{array}{l}10(3 \cdot 7 \\
\text { per cent.) }\end{array}$ & $\begin{array}{l}33(12 \cdot 2 \\
\text { per cent.) }\end{array}$ & $\begin{array}{l}96(35 \cdot 6 \\
\text { per cent.) }\end{array}$ & $\begin{array}{l}83(30 \cdot 8 \\
\text { per cent.) }\end{array}$ & $\begin{array}{l}33(12 \cdot 2 \\
\text { per cent.) }\end{array}$ & $\begin{array}{l}13(4.8 \\
\text { per cent.) }\end{array}$ & $\begin{array}{l}2(0 \cdot \tau \\
\text { per cent.) }\end{array}$ \\
\hline
\end{tabular}


of the phosphatase ran parallel with the degree of rickets as judged by clinical evidence. This correlation is not a close one and cases with mild rickets have been observed with a much higher phosphatase than was found in other patients with more marked signs of rickets (table 4). In individual

TABLE 4.

EXAMPLES OF INCONSISTENCY BETWEEN HEIGHT OF PLASMA POSPHATASE AND SEVERITY OF CLINICAL FINDINGS IN RICKETS.

\begin{tabular}{|c|c|c|c|c|c|c|}
\hline NAME & Chrs. & X-RAY & $\begin{array}{c}\text { Phospha- } \\
\text { TASE, CTITS }\end{array}$ & $\begin{array}{l}\text { Ca MGM. } \\
\text { PER CENT. }\end{array}$ & $\begin{array}{l}\text { P. MGM. } \\
\text { PER CENT. }\end{array}$ & $\mathrm{Ca} \times \mathbf{P}$ \\
\hline W. C. & + & $\mathbf{N}$ & $22 \cdot 8$ & $9 \cdot 9$ & $4 \cdot 5$ & $44 \cdot 6$ \\
\hline R. F. & $\div$ & $\mathbf{N}$ & $26 \cdot 7$ & $9 \cdot 0$ & $3 \cdot 6$ & $\mathbf{3 5} \cdot \mathbf{3}$ \\
\hline J. $\mathbf{M}$. & + & $\mathbf{N}$ & $24-7$ & - & $4 \cdot 8$ & - \\
\hline I. A. & $+t-1$ & $+\quad+$ & $16 \cdot 1$ & $10 \cdot 9$ & $3 \cdot 1$ & 33.8 \\
\hline R. D. & +++ & $+\quad \div$ & $17 \cdot 9$ & - & $2 \cdot 1$ & - \\
\hline H. McL. & -++ & $+\quad+$ & $16 \cdot 0$ & - & $2 \cdot 9$ & 一 \\
\hline
\end{tabular}

TABLE 5 .

Plasma phosphatase aNd serty phosphorts ix rickets.

\begin{tabular}{|c|c|c|c|c|c|c|}
\hline \multirow[b]{2}{*}{$\begin{array}{l}\text { High phosphatase } \\
\text { Normal phosphatase }\end{array}$} & & \multirow[b]{2}{*}{$\begin{array}{l}\ldots \\
\ldots\end{array}$} & \multicolumn{2}{|c|}{$\begin{array}{l}\text { No. OF CASES WITHOUT } \\
\text { CONYLLSIONS. } \\
\text { SERLM P. } \\
\end{array}$} & \multicolumn{2}{|c|}{$\begin{array}{l}\text { No. OF CASES WITH } \\
\text { CONVLLSIONS. } \\
\text { SERLM P. } \\
\end{array}$} \\
\hline & $\begin{array}{l}\cdots \\
\cdots\end{array}$ & & $\begin{array}{r}\text { Low* } \\
143 \\
31\end{array}$ & $\begin{array}{c}\text { NorMaL } \\
73 \\
9\end{array}$ & $\begin{array}{c}\text { Low* } \\
35 \\
17\end{array}$ & $\begin{array}{c}\text { Normal } \\
33 \\
19\end{array}$ \\
\hline
\end{tabular}

* Below 4 mgm. per cent.

cases, however, the intensity of the rachitic processes can be measured by making observations during the stage of healing when it is found that the phosphatase is reduced as calcification returns to normal. It is evident that the height of the plasma phosphatase cannot be used as a means of comparing the severity of rickets in different patients, although as will be more fully discussed later it is of value in the estimation of the recovery process in the same patient.

\section{Relationship between the phosphorus and the phosphatase of the blood}

From table 5 it will be seen that of 174 cases of uncomplicated rickets with low serum phosphorus (below $4.0 \mathrm{mgm}$. per cent.) 143 (82.2 per cent.) had a high phosphatase, while of 216 cases with a high phosphatase, 143 $(66 \cdot 2$ per cent.) had a low serum phosphorus. It would appear therefore that in the absence of convulsions, a low value for serum phosphorus is generally accompanied by a high plasma phosphatase. The association is not so close in cases of convulsions since in this group, only $35(6 \pi \cdot 3$ per cent.) of the 52 patients with low phosphorus had a high phosphatase, while of 68 with high phosphatase, 33 (48.6 per cent.) had a normal phosphorus. The coefficient of correlation between the phosphorus and phosphatase values was determined in the whole series of cases and found to be low, only 68. $\tau$ per cent. of the cases with low phosphorus having high 
phosphatase. In individual rachitic patients simultaneous determinations of phosphatase and phosphorus show in some cases a considerable degree of association between the two values (fig. 1c, 3a). These results indicate

Fig. 1.

EFFECT OF ADEXOLIN 30 MINIMS THREE TIMES A DAY.

M. D.

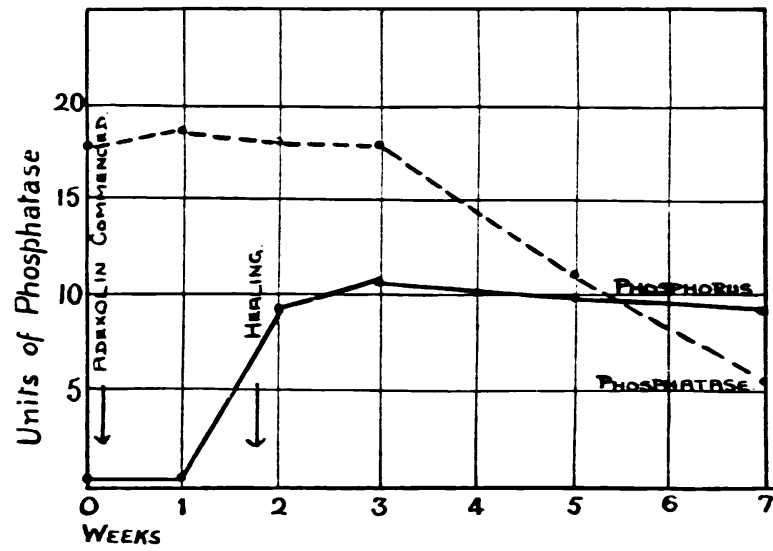

T. D.

B.

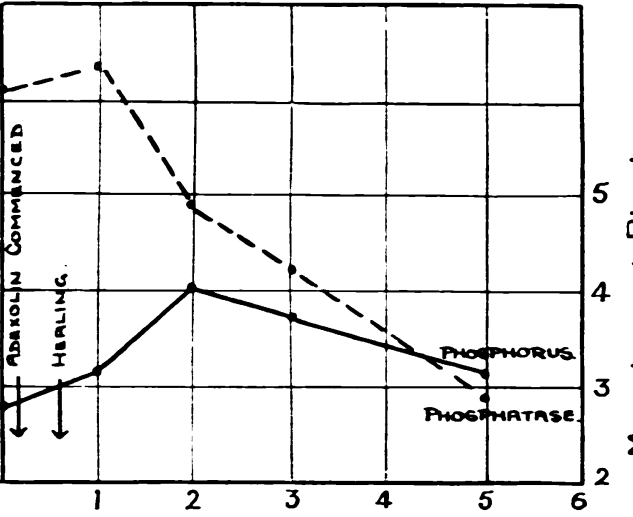

J. M. C.

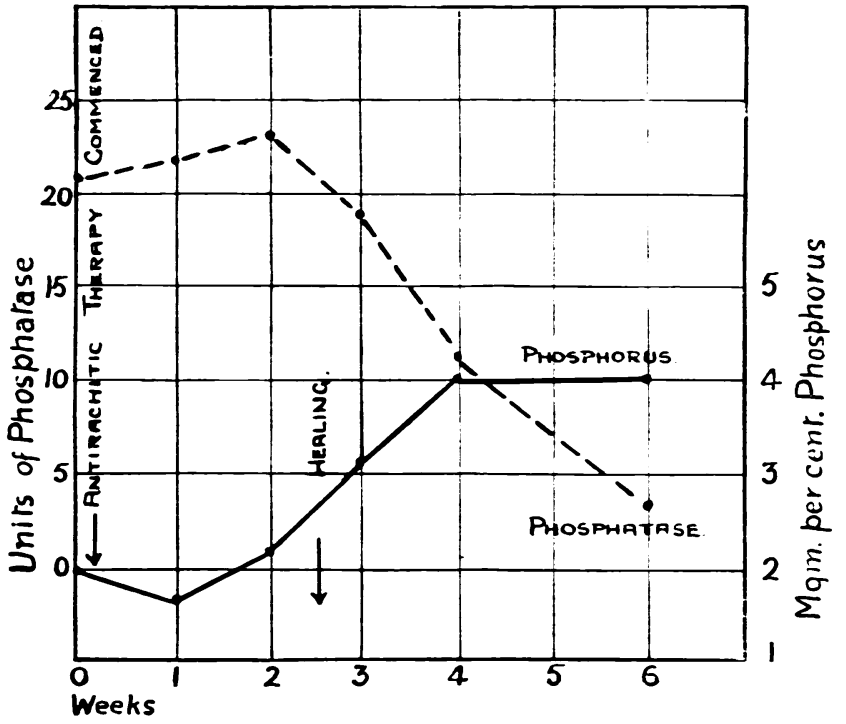

that the relationship between phosphatase and phosphorus is probably no more than a tendency to move in opposite directions. This is by no means a general rule: thus when tetant is present the serum phosphorus is frequently high and often a preliminary reduction occurs shortly after the commencement of antirachitic therapy. 
Fig. 2.

EFfect of COD LIVER OIL.

A.

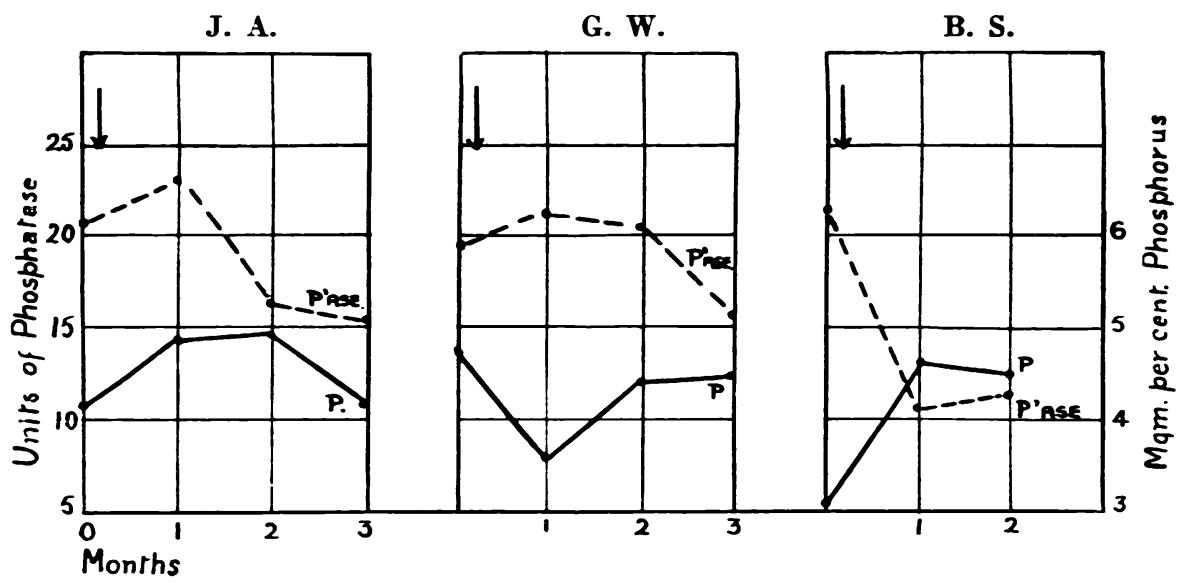

$\downarrow$ COD LIVER OIL BEGUN.

D.

D. $\mathbf{W}$.

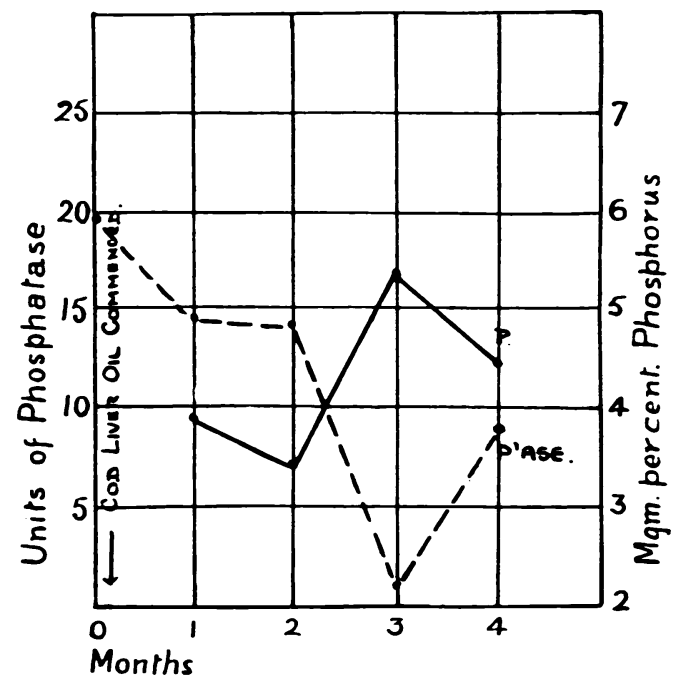


Fig. 3.

EFfect of irRadiated MILK.

A.

i. $\mathbf{N}$.

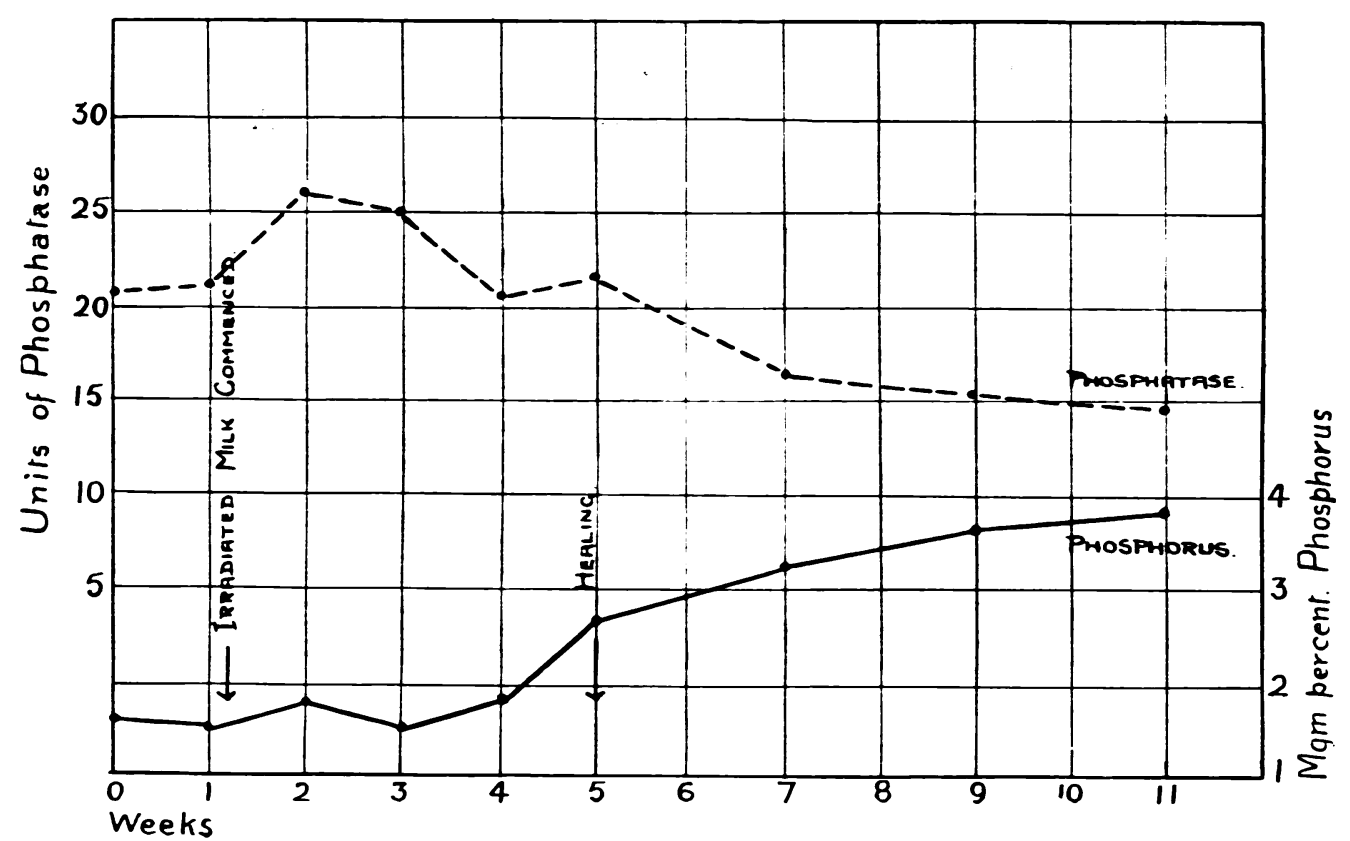

B.

D. B.

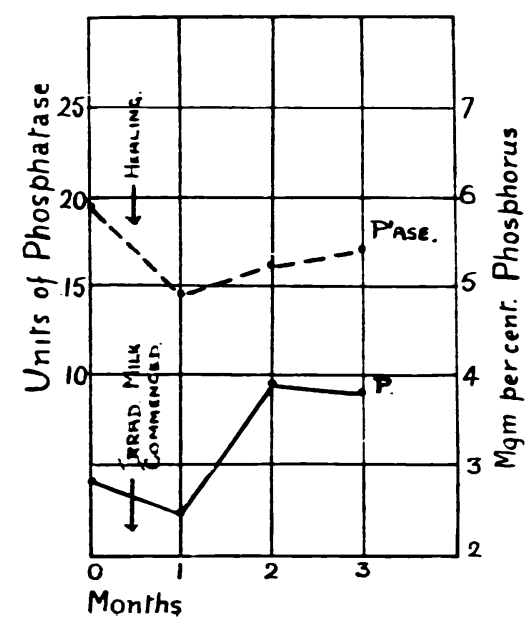




\section{Phosphatase and calcium-phosphorus product}

The association between these two values was also found to be close. Of 130 cases with product below 40, uncomplicated by convulsions, 109 (83.8 per cent.) had an increased phosphatase, while of 139 with a high phosphatase only 30 (21.6 per cent.) had a normal product (table 6). In

TABLE 6.

Plasma phosphatase aNd calcticm-Phosphorts prodtct in rickets.

\begin{tabular}{|c|c|c|c|c|c|c|}
\hline & & & \multicolumn{2}{|c|}{$\begin{array}{l}\text { No. of cases witholt } \\
\text { coNvllsions. } \mathrm{Ca} \times \mathrm{P} \text {. }\end{array}$} & \multicolumn{2}{|c|}{$\begin{array}{l}\text { No. OF cases With } \\
\text { convltsions. } C a \times P .\end{array}$} \\
\hline & & & Low* & Normal & Low* & NorMal \\
\hline High phosphatase & $\ldots$ & $\ldots$ & 109 & 30 & 45 & 14 \\
\hline Normal phosphatase & $\ldots$ & $\ldots$ & 21 & $\mathbf{3}$ & 19 & 15 \\
\hline
\end{tabular}

* Below 40.

the cases with convulsions there appeared to be a closer connection between phosphatase and the calcium phosphorus product than between phosphatase and phosphorus, due no doubt to the reduction of calcium compensating for the increase in phosphorus which may occur in the convulsions of tetany.

\section{The effect of administration of vitamin D}

Several investigators ${ }^{\mathrm{s}, 14}$ have shown that the administration of vitamin $D$ leads to a fall in the plasma phosphatase value. Fig. 1, 2, 3 show the results obtained in eight cases examined at frequent intervals. Several interesting points are demonstrated. In the first place it is evident that the plasma phosphatase may remain stationary when evidence of healing is obtained on the skiagram and even when the serum phosphorus is on the increase. This supports the view put forward by Bodansky and $\mathrm{Jaffe}^{6}$ that it is cnly a rising value for phosphatase which indicates active rickets. These workers state that a solitary high value for plasma phosphatase indicates merely the presence of rickets and not the absence of healing and that in active rickets the phosphatase content is increased. There has been an opportunity of observing the changes in plasma phosphatase in four cases of untreated rickets over periods of one to three weeks. In all four the phosphatase increased in value (table $\tau$ ) while the

TABLE $\pi$.

ShOWINg INCREASE OF PLASMA PHOSPHATASE WITHOLT TREATMENT.

\begin{tabular}{|c|c|c|c|}
\hline \multicolumn{2}{|c|}{ NAME } & Date & $\begin{array}{c}\text { Plasma phosphatase } \\
\text { LNITS }\end{array}$ \\
\hline \multirow[t]{2}{*}{ J. S. ... } & \multirow[t]{2}{*}{$\ldots$} & 18. 3.36 & $16 \cdot 3$ \\
\hline & & 9. 4.36 & $29 \cdot 3$ \\
\hline \multirow[t]{3}{*}{ D. McL. } & \multirow[t]{3}{*}{$\cdots$} & 20. 3.36 & $13 \cdot 2$ \\
\hline & & 24. 3.36 & $17 \cdot 0$ \\
\hline & & 14. 4.36 & $20 \cdot 4$ \\
\hline \multirow[t]{2}{*}{ H. McL. } & \multirow{2}{*}{$\cdots$} & 22.11 .35 & $16 \cdot 8$ \\
\hline & & 29.11.35 & $21 \cdot 0$ \\
\hline \multirow{2}{*}{ D. B. ... } & \multirow[t]{2}{*}{$\ldots$} & 30. 1.35 & $17 \cdot 7$ \\
\hline & & 11. 2.35 & $25 \cdot 5$ \\
\hline
\end{tabular}


skiagrams showed evidence of continued activity of the rachitic process. These results provide strong confirmation of Bodansky and Jaffe's view ${ }^{6}$.

Secondly, the initiation of antirachitic therapy is occasionally followed by a small but definite rise of the plasma phosphatase which may amount to two units. This is possibly related to the biphasic action of vitamin $D$ pointed out by Hottinger ${ }^{12}$ and by Morris, Graham and Ford ${ }^{13}$ who showed that shortly after the start of vitamin $D$ administration there may be a diminution of calcium retention even to the extent of a markedly negative balance.

Thirdly, the fall of phosphatase in every case occurred after the appearance of signs of healing on the skiagrams. Unless therefore a stationary value for the phosphatase is taken as evidence of healing, determination of the phosphatase content of plasma is not an earlier criterion of healing than that afforded by skiagrams. The serum phosphorus usually commenced to rise before there was any fall in phosphatase although the converse was found in one case.

Fourthly, it is clear that the greater the dosage of vitamin $\mathbf{D}$ the more rapid is the fall of the phosphatase value. Large doses of vitamin D (90 minims of ' adexolin' daily) led to a fall of the phosphatase value to within normal limits in five weeks. With moderate doses, however, the value did not fall to this level in three months (table 8). This, of course, is in

TABLE 8.

SHOWINg VARIATION IN FALL OF PHOSPHATASE With DIFFERENT DOSES OF VITAMIN D.

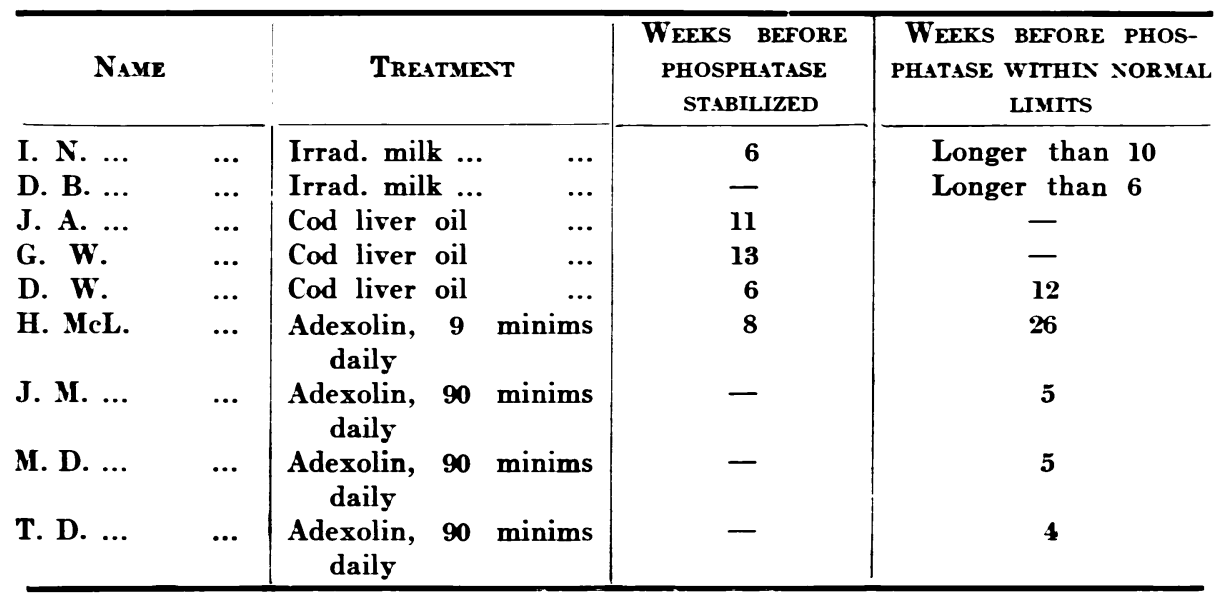

accord with general clinical experience that the rate of healing of rickets is dependent on the dosage of vitamin $D$. The fact that moderate doses of vitamin D may not produce a fall of plasma phosphatase to within normal limits for several months stresses the importance of a long continuance of antirachitic therapy even after clinical recovery is apparently complete, since metabolism cannot be considered to have become normal until phosphatase values have reached normal limits. 


\section{Significance of high plasma phosphatase}

Andersen ${ }^{14}$ believes that a high plasma phosphatase is indicative of an insufficient supply of vitamin $\mathbf{D}$, and support is lent to this conclusion by the finding that administration of vitamin $\mathbf{D}$ preparations leads to a diminution of the phosphatase value. This has been observed in a patient who did not show any clinical or x-ray signs of rickets. In this child administration of vitamin $D$ reduced the plasma phosphatase from $17 \cdot 8$ to 14.6 units in two weeks. Nevertheless it must be remembered that since high values are obtained in disturbances of bone metabolism such as Paget's disease and osteitis fibrosa, in which there is no evidence of a vitamin $D$ deficiency, it cannot be considered that a high plasma phosphatase necessarily indicates such a deficiency. The production of phosphatase by bone and other tissues is essentially a manifestation of cellular activity. Indeed it has been pointed out that cells which are functionally inactive such as those of the foetal kidney do not form phosphatase. Thus it would appear that the more active the tissue cells are, the more phosphatase will they produce. Presumably, therefore, the increase in plasma phosphatase in disturbances of bone metabolism indicates an increase in the activity of the bone cells. It has been shown by Bodansky and $\mathrm{Jaffe}^{6}$ that in healthy children there is a tendency for plasma phophatase to increase at periods when growth is most marked. Per contra Smith ${ }^{10}$ has shown that conditions characterized by cessation of growth such as cretinism, scurvy and achondroplasia are associated with low plasma phosphatase, and the present findings in these conditions are similar. Normally an increased activity in bone cells is accompanied by an increased amount of ossification. For this an adequate supply of calcium and phosphorus is required. When the supply available does not satisfy the requirements of the bone cells increasing amounts of phosphatase may be left unused and flow over, as it were, into the plasma. This would occur either because of absolute or relative deficiency in the supply of calcium, phosphorus or vitamin $\mathbf{D}$ or alternatively when the cellular activity of osseous tissue reaches such a height that it is impossible with maximal supplies of vitamin $\mathbf{D}$ and minerals to satisfy its requirements. In this connection the following observation is of interest.:-

A child aged two years with bony deformities due to old rickets was put on a diet deficient in lime in order to soften the bones and thereafter correct the abnormal curvatures. After a period of two months on this diet the plasma phosphatase showed a definite increase although the child received vitamin $D$ by mouth and was exposed to sunshine (table 9 ).

TABLE 9.

Effect of low calcily diet (CONtainisg vitayin D) ON PlasMa phosphatase.

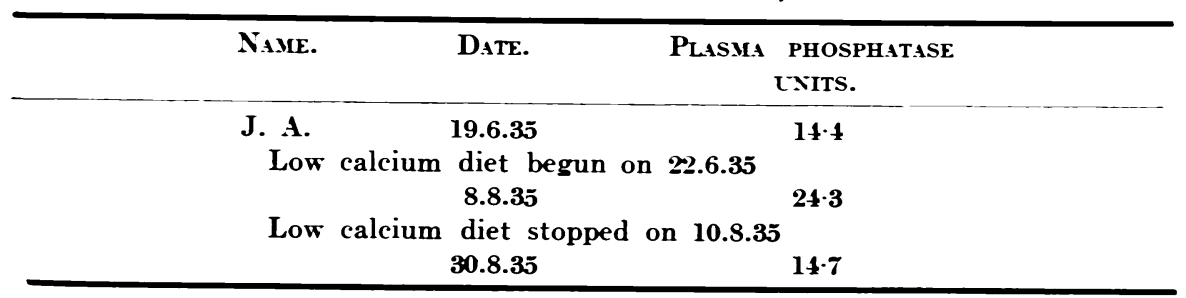


This finding supports the view that the plasma phosphatase rises when the supply of available calcium does not meet the demand of the active bone cells. In rickets, as long as more minerals are required for bone formation than are being supplied, the plasma phosphatase will tend to rise, but as soon as the supply becomes sufficient to meet the demand the phosphatase will cease to rise and will ultimately fall to within normal limits. In view of the great calcium depletion of the bones it is not surprising that with the usual doses of vitamin $D$, a relatively long time is required for the phosphatase to regain the levels observed in health.

It must be emphasized that the conjunction of mineral depletion and grossly inadequate supply of minerals is not alone sufficient to cause an increase of plasma phosphatase. This is well demonstrated in coeliac disease and renal dwarfism. In both of these conditions there is frequently marked osteoporosis with low values for phosphatase. In coeliac disease the association of mineral deficiency with hyporitaminosis $D$ is not sufficient to produce an increase in plasma phosphatase until growth is resumed, i.e., until the bone cells become active, when rickets becomes evident. In renal dwarfism, on the other hand, in which condition there is no deficiency in the vitamin $\mathbf{D}$ intake but a marked inability to utilize calcium and phosphorus effectively there is no rise in phosphatase until, as sometimes occurs, a period of growth takes place when rickets appears with a coincident rise in plasma phosphatase. In both conditions it is the inadequacy of the effective mineral supply to the needs of the active bone cells that produces the rise in plasma phosphatase.

The presence of a high plasma phosphatase in the absence of clinical or radiographic evidence of rickets may be attributed to an insufficient supply of calcium to meet the demands of the active bone cells. Whether or not this is termed rickets is a matter of opinion, although it is interesting that five patients who on the first examination had a high phosphatase but no clinical signs of rickets, some nine months later were found to show definite evidence of rickets (table 2). In the first nine months of life an insufficient intake of calcium must seldom occur. It is probable that, if a high plasma phosphatase indicates an inadequate supply of lime to the bone cells, it is almost certainly due at this age to an insufficiency in vitamin D. This was the case with the patient already mentioned whose plasma phosphatase was reduced after fourteen days of vitamin $\mathrm{D}$ therapy although at no time were there signs of rickets.

The rare occurrence of a normal phosphatase with signs of active rickets might be explained on the assumption that growth had temporarily ceased. As a result, even the negligible amount of minerals retained would suffice for the diminished activities of the bone cells. 


\section{Summary and conclusions}

The plasma phosphatase was estimated in a group of 506 infants and children below the age of two years. In $84 \cdot 1$ per cent. of the cases with clinical or $x$-ray evidence of rickets the plasma phosphatase was increased above normal limits. It is suggested that a rise in plasma phosphatase is an earlier manifestation of the rachitic state than that provided by ordinary clinical or radiographic examination. A rough parallelism was observed between the height of the phosphatase and the severity of the rachitic process, but it is pointed out that the level of the phosphatase cannot be taken as an index of that severity in the individual patient. A moderate degree of correlation was observed between the rise in phosphatase and the fall in phosphorus and calcium phosphorus product, especially the latter, and it would appear that of the three, an increase in plasma phosphatase is the most delicate test of the rachitic state, although it would be unwise to use alteration in phosphatase alone as conclusive evidence of the presence or absence of rickets.

In untreated active rickets the plasma phosphatase continues to rise. Administration of vitamin D prevents this rise and in two to three weeks causes a fall. The rate of fall depends upon the dosage of vitamin $D$, being much more rapid with large amounts. On ordinary therapeutic doses normal limits may not be reached for over three months. The significance of a high plasma phosphatase is discussed, and it is suggested that the phosphatase is increased whenever the supply of calcium is unable to meet the demand of the bone cells as a result of defective intake of minerals or vitamin D.

Thanks are due to Dr. D. Campbell Suttie and Dr. Balfour Black, for their help in the interpretation of the skiagrams, and to Prof. G. B. Fleming and Dr. Stanley Graham for permission to study the patients in their wards. The expenses of the research were partly defrayed by a grant from the Medical Research Council.

\section{REFERENCES}

1. Freudenberg, E., In Pfaundler, M., \& Schlossmann, A., Diseases of Children, Philadel., 1935, II, 71 .

2. Hess, A. F., Lewis, J. M., \& Rivkin, H., J. Amer. Med. Ass., Chicago, 1930, XCIV, 1885.

3. Warkany, J., Amer. J. Dis. Child., Chicago, 1935, XLIX, 318.

4. Stearns, G., \& Boyd, J. D., J. Clin. Inzest., New York, 1931, X, 59.

5. Marfan, A. B., Presse méd., Paris, 1952, XL, 561.

6. Bodansky, A., \& Jaffe, H. L., Amer. J. Dis. Child., Chicago, 1934, XLVIII, 1268; Arch. Itern. Med., Chicago, 1934, LIV, 88.

7. Kay, H. D., J. Biol. Chem., Baltimore, 1930, LXXXIX, 249.

8. Smith, J., \& Maizels, M., Arch. Dis. Childh., London, 1932, VII, 149. 
9. Stearns, G., \& Warweg, E., J. Biol. Chem., Baltimore, 1933, CII, 749.

10. Smith, J., Arch. Dis. Childh., London, 1933, VIII, 215.

11. Jenner, H. D., \& Kay, H. D., Brit. J. Exp. Path., London, 1932, XIII, 22.

12. Hottinger, A., Z. Kinderheilk., Berlin, 1929, XLVII, 341.

13. Morris, N., Graham, S., \& Ford, F. J., Acta Paediatr., Cppsala, 1935, XVIII, 50.

14. Andersen, O., Jahrb. Kinderh., Berlin, 1935, CXLIV, 206. 